\title{
Signaling Role of Adipocyte Leptin in Prostate Cell Proliferation Induced by Trichomonas vaginalis
}

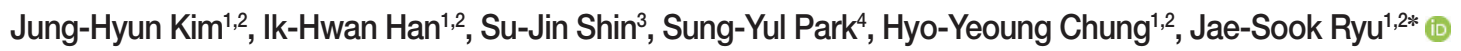 \\ ${ }^{1}$ Department of Environmental Biology and Medical Parasitology, Hanyang University College of Medicine, Seoul 04763, Korea; ${ }^{2}$ Department of \\ Biomedical Science, Graduate School of Biomedical Science \& Engineering, Hanyang University, Seoul 04763, Korea; ${ }^{3}$ Department of Pathology, \\ Gangnam Severance Hospital, Yonsei University College of Medicine, Seoul 06273, Korea; ${ }^{4}$ Department of Urology, Hanyang University College of \\ Medicine, Seoul 04763, Korea
}

\begin{abstract}
Leptin is a type of adipokine mainly produced by adipocytes and reported to be overproduced in prostate cancer. However, it is not known whether it stimulates the proliferation of prostate cells. In this study, we investigated whether benign prostatic hyperplasia epithelial cells (BPH-1 cells) infected with Trichomonas vaginalis induced the proliferation of prostate cells via a leptin signaling pathway. To investigate the effect of crosstalk between adipocyte leptin and inflamed epithelial cell in proliferation of prostate cells, adipocytes 3T3-L1 cells were incubated in conditioned medium of BPH-1 cells infected with $T$. vaginalis (T. vaginalis-conditioned medium, TCM), and then the adipocyte-conditioned medium (ATCM) was identified to cause proliferation of prostate cells. BPH-1 cells incubated with live T. vaginalis released pro-inflammatory cytokines, and conditioned medium of these cells caused migration of adipocytes. When prostate stromal cells and BPH-1 cells were incubated with adipocyte conditioned medium containing leptin, their growth rates increased as did expression of the leptin receptor (known as OBR) and signaling molecules such as JAK2/STAT3, Notch and survivin. Moreover, blocking the OBR reduced this proliferation and the expression of leptin signaling molecules in response to ATCM. In conclusion, our findings show that inflamed BPH-1 cells infected with $T$. vaginalis induce the proliferation of prostate cells through leptin-OBR signaling. Therefore, it is likely that $T$. vaginalis contributes to prostate enlargement in $\mathrm{BPH}$ via adipocyte leptin released as a result of inflammation of the prostate.
\end{abstract}

Key words: Trichomonas vaginalis, leptin, prostatic hyperplasia, cell proliferation, adipocyte

\section{INTRODUCTION}

The protozoan parasite, Trichomonas vaginalis, is the cause of trichomoniasis, a common sexually transmitted disease [1]. The World Health Organization estimates that over half of the 143 million new T. vaginalis infections each year involve males [2]. The majority of infections in men are asymptomatic and remain undiagnosed and untreated, and are thought to result in persistent prostatic infection [3]. Trichomonas vaginalis has been detected in prostate tissue in prostate cancer and benign prostatic hyperplasia (BPH), as well as in the urine of patients with prostatitis [4-6]. We have shown that T. vaginalis infection causes acute and chronic inflammation within the parenchyma of the prostate gland [7], and prostate inflammation, in-

\footnotetext{
- Received 3 February 2021, revised 6 May 2021, accepted 7 May 2021.

*Corresponding author (jsryu@hanyang.ac.kr)

(C) 2021, Korean Society for Parasitology and Tropical Medicine

This is an Open Access article distributed under the terms of the Creative Commons

Attribution Non-Commercial License (https://creativecommons.org/licenses/by-nc/4.0) which permits unrestricted non-commercial use, distribution, and reproduction in any

medium, provided the original work is properly cited.
}

cluding the production of cytokines, appears to be a cause of $\mathrm{BPH}$ and prostate cancer $[8,9]$. Inflammatory mediators are secreted by the prostatic stroma consequent upon aging, and the levels of these mediators are sufficient to increase the proliferative rate of both epithelial and stromal fibroblasts [10]. Although, inflammation may play a role in the development of benign proliferative diseases of the prostate such as BPH, the connections between inflammation, T. vaginalis infection and prostate enlargement are not fully understood.

Benign prostate hyperplasia (BPH) occurs clinically in about $50 \%$ of men over the age of 70 [11]. It is not clear what elicits $\mathrm{BPH}$, but aging may be a prerequisite for its induction [12]. Recently, some reports have also highlighted the key roles of hormonal alterations, metabolic syndrome and obesity in the pathogenesis of BPH [13-16].

Obesity causes many physiological problems and can induce chronic inflammation [17]. In addition, infection by Neospora caninum, a protozoon, raises serum leptin levels and contributes to long-term inflammation in adipose tissue [18]. Adipocytes influence the endocrine system and immune re- 
sponses through several cytokine-like mediators known as adipokines. Leptin is an adipokine originally identified as a key molecule in the regulation of food intake and body weight. It interacts with other hormones and energy regulators, mediating the effects of insulin, glucagon, insulin-like growth factor, growth hormone, glucocorticoids, cytokines, and metabolites [19]. Obesity is associated with several diseases, and many reports have suggested a link between leptin and cancer growth. Leptin also stimulates the growth of prostate, breast, lung, ovarian and pancreatic cancer cells [20-24]. BPH is closely linked to obesity, and abdominal obesity and serum leptin levels influence prostate growth [25] and are high-risk factors for clinical BPH [18]. However, the connection between BPH and obesity is not yet fully understood at the molecular level. Furthermore, it is not clear whether leptin influences the progression of $\mathrm{BPH}$.

We showed previously that BPH epithelial cells that had been infected with $T$. vaginalis caused inflammation, and induced the proliferation of prostate stromal cells by activating of mast cells [26]. Subsequently, inflammatory mediators released from the proliferating stromal cells by T. vaginalis infection were shown to induce the proliferation of BPH epithelial cells [27]. However, it is not known how the crosstalk between T. vaginalis infection and adipocytes causes the proliferation of prostate cells. In particular, it is not known whether leptin released from the adipocytes is directly responsible for the proliferation of normal and benign prostate cells. To assess whether inflammation due to T. vaginalis infection in obese conditions is involved in the progression of $\mathrm{BPH}$, we examined whether adipocyte, incubated with culture supernatants of BPH epithelial cells infected with T. vaginalis, induces the proliferation of prostate stromal and epithelial cells by production of leptin. Our findings suggest that BPH epithelial cells infected with T. vaginalis induce adipocyte migration and activation and that in turn, the adipocytes produce leptin, which stimulates the proliferation of prostate cells.

\section{MATERIALS AND METHODS}

\section{Cultivation of parasite and host cells}

Trichomonas vaginalis isolate T016, human BPH epithelial cell line (BPH-1 cell) and human prostate stromal cell line (WPMY-1 cell) were cultured as described in our previous study [26]. All the cells were incubated in $5 \% \mathrm{CO}_{2}$ at $37^{\circ} \mathrm{C}$.

\section{Cultivation of adipocytes}

Mouse preadipocyte cells (3T3-L1 cell) were a gift from Prof. Jae-woo Kim (Yonsei University). They were grown in DMEM containing $10 \%$ bovine calf serum (BCS, Rosedale, Auckland, New Zealand) and $1 \times$ penicillin-streptomycin solution. To induce differentiation, 2-day post-confluent 3T3-L1 cells were incubated in DMEM containing 10\% FBS, 0.5 mM 3-isobutyl1-methylxanthine, $1 \mu \mathrm{M}$ dexamethasone, and $10 \mu \mathrm{g} / \mathrm{ml}$ insulin for 3 days. The cells were then cultured in DMEM containing $10 \%$ FBS and insulin for another 2 days, after which they were grown in DMEM containing 10\% FBS. Lipid droplets in the cells were detected by oil-red-O staining [28].

\section{Preparation of conditioned media}

To probe the effect of interactions between adipocytes and inflamed epithelial cells on the proliferation of prostate cells, in vitro co-cultures of adipocytes and BPH-1 cells infected with T. vaginalis were established. Conditioned media were made as described previously [26]. Briefly, BPH-1 cells were seeded at $1 \times 10^{5}$ cells/well in complete medium in 12-well plates. After $24 \mathrm{hr}$, the medium was changed to serum-free medium and the cells were cultured for another $24 \mathrm{hr}$ to stabilize them. They were then incubated with or without live T. vaginalis in a ratio of 1:10 for $6 \mathrm{hr}$ and supernatants were collected, filtered through $0.2 \mathrm{~mm}$ filters, and stored frozen. The culture supernatants of the BPH-1 cells incubated with and without T. vaginalis were named T. vaginalis-conditioned medium (TCM) and conditioned medium (CM), respectively. Differentiated adipocytes were incubated with TCM and CM, in the same way, yielding the conditioned media ATCM and ACM. Final concentrations of the conditioned media used for various assays were adjusted to $10 \%$ with cell culture medium.

\section{Measurement of cytokines}

Cytokine concentrations in conditioned media were measured by ELISAs. Concentrations of cytokines IL-6, CXCL8, CCL2, and IL-1 $\beta$ were measured with human ELISA sets (BD Biosciences, San Jose, California, USA) and concentrations of adipokines CXCL1, IL-6, and CCL2 were measured with mouse ELISA sets (BD Biosciences). Leptin levels were measured with a mouse leptin ELISA kit (Abcam, Cambridge, Massachusetts, USA).

\section{Preadipocyte chemotaxis assay}

Chemotaxis was assessed using 24-well plates fitted with $5 \mathrm{~mm}$ pore polycarbonate membrane inserts. The chemotactic 
index was calculated as described in our previous study [28]. Briefly, the lower wells were filled with $350 \mathrm{ml}$ of TCM, and polycarbonate membrane inserts were placed over the lower wells. For adhesion of the cells, the filters were pretreated with human plasma fibronectin $(100 \mathrm{mg} / \mathrm{ml})$ overnight at $4^{\circ} \mathrm{C}$, and air-dried for $30 \mathrm{~min}$. The upper wells were filled with $200 \mathrm{ml}$ of preadipocyte cell $\left(2 \times 10^{5}\right.$ cells/well $)$ in serum-free medium, and the plates were incubated for $24 \mathrm{hr}$ at $37^{\circ} \mathrm{C}$. After incubation, cells that did not migrate through the pores were wiped off the membranes with cotton swabs. The cells that had migrated to the underside of the membrane were fixed in methanol and stained with Giemsa stain solution, and 5 randomlyselected fields per membrane were counted under a light microscope. The chemotactic index was calculated from the number of cells that migrated relative to the control.

\section{Proliferation and invasion assays}

To measure cell proliferation, wound healing assay and BrdU incorporation assay were used. For wound healing assays, cultured prostate cells that had reached confluence were wounded by scraping across the surface of the well with a sterile micropipette tip. The cells were washed immediately and incubated in 10\% ATCM for $48 \mathrm{hr}$. Before and after incubation, at least ten different fields of the wounded area of each sample were photographed with an inverted microscope (Leica, Las software) [26]. We used the 5-bromo-20-deoxyuridine (BrdU) incorporation assay to detect DNA synthesis following ATCM treatment of prostate cells. For the BrdU assay, prostate cells were seeded at $5 \times 10^{4} /$ well on sterile cover glasses in 12 well plates, allowed to adhere overnight and cultured with $10 \%$ ATCM for $48 \mathrm{hr}$. During that time, BrdU (10 $\mu \mathrm{g} / \mathrm{ml})$ was added to the cells once a day. The cells were fixed for $10 \mathrm{~min}$ at $-20^{\circ} \mathrm{C}$, and denatured for $30 \mathrm{~min}$ at $37^{\circ} \mathrm{C}$. For blocking and permeabilization, the cells were placed in blocking buffer for $1 \mathrm{hr}$ at room temperature. They were then incubated with antiBrdU antibody (Abcam) overnight at $4^{\circ} \mathrm{C}$, and stained with $\mathrm{Al}$ exa 594-labelled goat anti-rabbit lgG (Invitrogen, Carlsbad, California, USA) at $37^{\circ} \mathrm{C}$ for $1 \mathrm{hr}$. They were mounted in Vectashield mounting medium (Vector Laboratories, Burlingame, California, USA) with DAPI to visualize nuclei. Fluorescence was measured with a fluorescence microscope (Leica, Las software). The invasiveness of prostate stromal cells treated with conditioned medium was tested according to the protocol described in our previous report [26].
Immunofluorescence detection of the leptin receptor

The leptin receptor is known as LEP-R or OB-R and has been used as OBR in several papers. To observe expression of the leptin receptor (OBR) on the surface of prostate cells, we used an immunofluorescence assay [26]. Transmembrane OBR, which belongs to the cytokine receptor superfamily, mediates the effects of leptin. Prostate cells were seeded at $2 \times 10^{5}$ cells/ well on sterile cover glasses in 12-well plates and cultured in complete medium. After overnight incubation, the medium was changed to ATCM, and the cells were cultured at $37^{\circ} \mathrm{C}$ for $24 \mathrm{hr}$. They were then washed, fixed with $4 \%$ paraformaldehyde for $10 \mathrm{~min}$ at $-20^{\circ} \mathrm{C}$ and blocked with $0.1 \%$ normal goat serum for $1 \mathrm{hr}$. The cover glasses were incubated with antiOBR antibody (Abcam) overnight at $4^{\circ} \mathrm{C}$, washed and stained with Alexa 594-labelled goat anti-rabbit $\operatorname{lgG}$ (Invitrogen) at $37^{\circ} \mathrm{C}$ for $1 \mathrm{hr}$. The cells were mounted in Vectashield mounting medium (Vector Laboratories) with DAPI to visualize nuclei. Fluorescence was measured with a fluorescence microscope (Leica, Las Software).

\section{Reverse transcription PCR (RT-PCR) and quantitative real-time PCR (Q-PCR)}

Levels of mRNA in T. vaginalis-treated BPH-1 cells and TCMtreated 3T3-L1 cells were measured by RT-PCR [26]. BPH-1 cells were seeded at $2 \times 10^{5}$ cells/well in 24-well plates in culture medium. After overnight incubation, the medium was changed to serum-free medium and then live T. vaginalis was added. In case of 3T3-L1 cells, cells were seeded at $5 \times 10^{4}$ cells/well on 24 -well plates with the culture medium. The medium of adipocytes replaced to serum-free medium with 10\% TCM. mRNA levels of leptin signaling molecules were examined by Q-PCR [26]. Prostate cells were seeded at $2 \times 10^{5}$ cells/well in 24-well plates with culture medium. After overnight incubation, the medium was changed to serum-free medium with $10 \%$ ATCM. Anti-OBR antibody was used to block leptin signaling. After reaction, the cells were collected and total RNA was extracted using Tri-RNA reagent (Favorgen Biotech Corp, Kaohsiung, Taiwan). RNA samples were reverse transcribed to CDNA using Maxime RT preMix (Oligo (dt) 15 Primer) (iNtRON Biotechnology, Sungnam, Korea), and the cDNA was used as template for subsequent PCR amplification using following gene-specific primers. Human CXCL8; 5'-GGCAGCTTCCTGATTTCTG-3', 5'-CGCAGTGTGGTCCACTCTCA-3', Human CCL2; 5'-CAAGCAGAAGTGGGTTCAGGA-3', 5'-TCTTCGGAGTTTGGGTTTGC-3', Human IL-6; 5'-TGGCTGCAGGACAT- 
GACAACT-3', 5'-ATCTGAGGTGCCCATGCTACA-3', Human IL$1 \beta ;$ 5'-CTGATGGCCCTAAACAGATGAAG-3', 5'-GGTCGGAGATTCGTAGCAGCTGGAT-3', Human JAK2; 5'-GAGCCTATCGGCATGGAATA-3', 5'-ACTGCCATCCCAAGACATTC-3', Human STAT3; 5'-TGTGCGTATGGGAACACCTA-3', 5'-AGAAGGTCGTCTCCССCTTA-3', Human Notch1; 5'-GAGGCGTGGCAGACTATGC-3', 5'-CTTGTACTCCGTCAGCGTGA-3', Human Jagged1; 5'-TCGGGTCAGTTCGAGTTGGA-3', 5'-AGGCACACTTTGAAGTATGTGTC-3', Human Jagged2; 5'-AGCTGGACGCCAATGAGTG-3', 5'-GTCGTTGACGTTGATATGGCA-3', Human survivin; 5'-TCCACTGCCCCACTGAGAAC-3', 5'-TGGCTCCCAGCCTTCCA-3', Mouse leptin; 5'-TGCTGCAGATAGCCAATGAC-3', 5'-GAGTAGAGTGAGGCTTCCAGGA-3', $\beta$-actin; 5'-CCAGAGCAAGAGAGGTATCC-3', 5'-CTGTGGTGGTGAAGCTGTAG-3'. Target mRNA was amplified with Maxime PCR PreMix (i-StarTaq) (iNtRON Biotechnology) using a Mastercycler (Eppendorf, Hamburg, Germany) for RT-PCR, and PCR products were separated by agarose gel electrophoresis. Bands were visualized with StaySafe Nucleic Acid Gel stain (RBC, Banqiao, New Taipei, Taiwan) and identified using an ExcelBand $^{\mathrm{TM}} 100$ bp+3K DNA Ladder (SMOBIO, Hsinchu, Taiwan). For quantitative real-time PCR, target mRNA was amplified using a LightCycler 480 SYBR Green I Master (Roche Life Science, Mannheim, Germany) and analyzed with the LightCycler 480 Software (Roche Life Science). $\beta$-actin was used as an internal control.

\section{Western blot analysis}

Cells were harvested and lysed in PRO-PREP protein extraction solution (iNtRON Biotechnology). Cell lysates were scraped, and protein concentrations were measured with the Bradford assay. Equal amounts of protein were denatured in $5 \times$ protein sample buffer (ELPIS biotech, Daejeon, Korea), separated by SDS-PAGE on 12\% polyacrylamide gel, and transferred to Immun-Blot ${ }^{\circledR P V D F}$ membranes (Bio-Rad, Quarry Bay, Hong Kong). The membranes were blocked with 3\% bovine serum albumin, and probed with the following primary antibodies overnight at $4^{\circ} \mathrm{C}$ : anti-leptin antibody (Abcam), anti-p-JAK2 antibody (Abcam), anti-p-STAT3 antibody (Cell signaling, Danvers, Massachusetts, USA), anti-Notch1 antibody (bioworld, Dublin, Ohio, USA), anti-NICD antibody (Abcam), anti-Jagged1 antibody (Abcam), anti-survivin antibody (Enzo Life Sciences, Farmingdale, New York, USA) or $\beta$-actin polyclonal antibody (Abcam). After washing, the membranes were incubated with goat anti-rabbit IgG antibody
$(\mathrm{H}+\mathrm{L})$, HRP conjugated (Bioss Antibodies, Woburn, Massachusetts, USA) for $1 \mathrm{hr}$ at room temperature, blots were visualized using Chemiluminescent Sensitive Plus HRP Microwell and/or Membrane Substrate (SurModics, Eden Prairie, Minnesota, USA) and signals were measured with a Chemi-Doc ${ }^{\circledR}$ (Bio-Rad, Hercules, California, USA) [26].

\section{Statistical analysis}

Statistical analyses were performed using SPSS statistical software, version 21 (IBM, Chicago, Illinois, USA). The MannWhitney $U$ test was used to compare results, and 2 tailed $P$ values $<0.05$ were considered statistically significant. All data are expressed as means \pm SEMs of three to four independent experiments.

\section{Ethical statement}

This study was approved by the Institutional Review Board of Hanyang University Hospital (IRB No. 2019-04-011-002). Waiver of informed consent for this study was obtained from IRB based on the retrospective analyses of archived tissues and clinical data.

\section{RESULTS}

\section{Cytokine production by BPH epithelial cells cocultured with Trichomonas vaginalis}

We first examined cytokine production by BPH-1 cells incubated with T. vaginalis (1:10) for $6 \mathrm{hr}$. The BPH-1 cells incubated with T. vaginalis released cytokines IL-6 $(448.8 \mathrm{pg} / \mathrm{ml})$, CXCL8 (548.6 pg/ml), CCL2 (435.9 pg/ml) and IL-1 $\beta$ (147.5 $\mathrm{pg} / \mathrm{ml}$ ), and cytokine production was significantly higher than in the absence of T. vaginalis $(P<0.05 ;$ Fig. $1 \mathrm{~A})$. Similarly, cytokine mRNA levels of cells incubated with $T$. vaginalis were higher than those incubated without T. vaginalis (Fig. 1B). T. vaginalis was confirmed to cause inflammatory response in BPH-1 cells. Culture supernatants of BPH-1 cells incubated with and without T. vaginalis were designated T. vaginalis-conditioned medium (TCM) and conditioned medium (CM), respectively. To identify lipid droplets accumulated in the cytoplasm of mature adipocytes, Oil-Red O staining was performed. Lipid accumulation of the adipocytes was observed in red (Fig. 1C). 

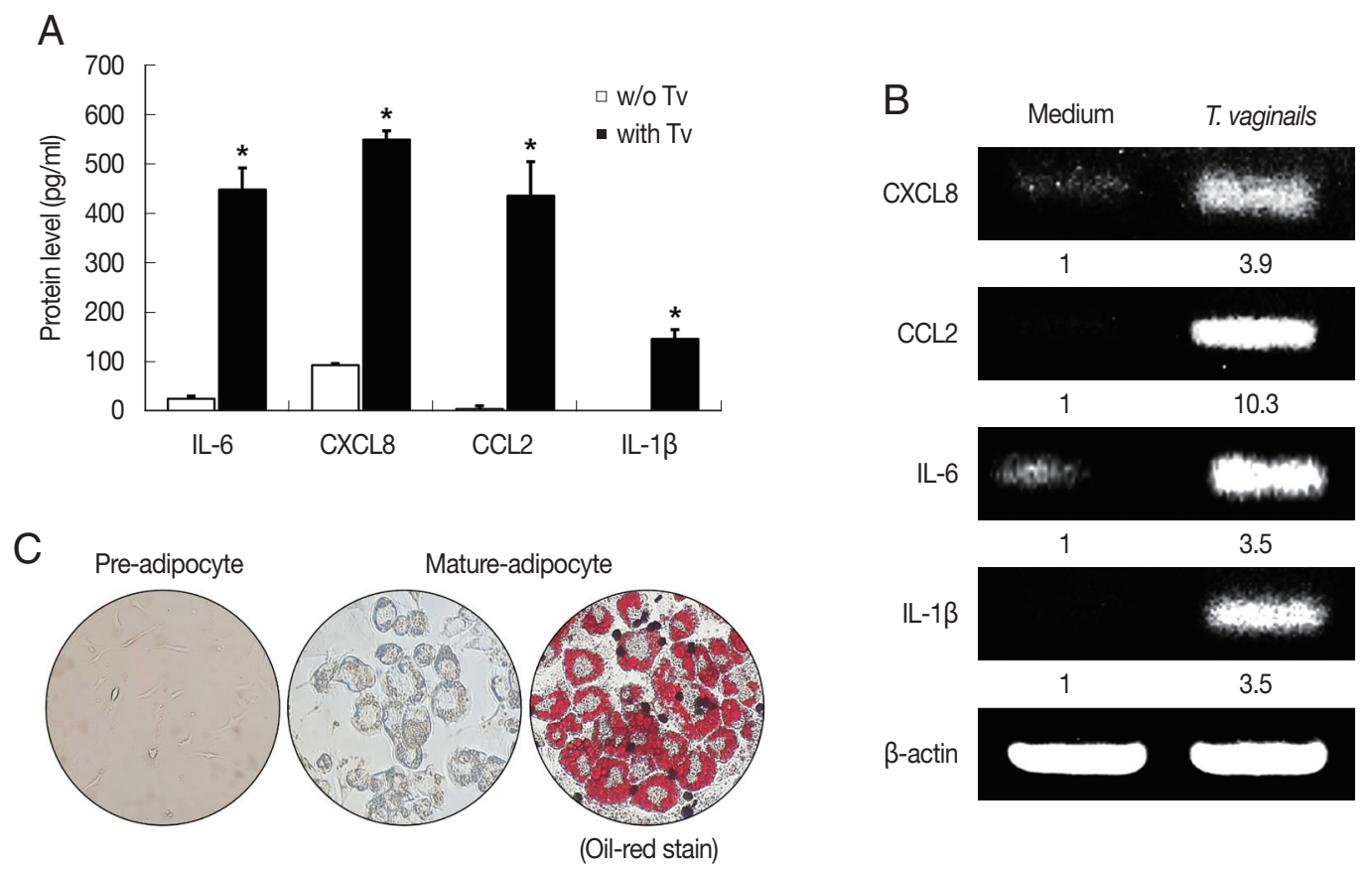

Fig. 1. Cytokine production by benign prostate hyperplasia-1 $(\mathrm{BPH}-1)$ cells infected with Trichomonas vaginalis, and differentiation of preadipocytes (3T3-L1) into mature adipocytes. To examine cytokine production, BPH-1 cells were incubated with live T. vaginalis (TV). Cytokines (IL-6, CXCL8, CCL2, and IL-1 $\beta$ ) and their mRNAs were measured by ELISA (A) and RT-PCR (B), respectively. Medium, culture supernatant of $\mathrm{BPH}-1$ cells not exposed to $T$. vaginalis. ${ }^{*} P<0.05$ versus w/o T. vaginalis. To identify lipid droplets accumulated in the cytoplasm of mature adipocytes, oil-Red $\mathrm{O}$ staining was performed. Lipid accumulation of the adipocytes was observed in red (C).

\section{Migration of preadipocytes, and adipokine expression in} adipocytes induced by TCM

Recently it was reported that pre-adipocytes are recruited preferentially to prostate cancer tissue rather than to surrounding normal prostate tissue [29]. We examined the effect of TCM on the migration of 3T3-L1 cells using a chemotaxis assay. Chemotaxis by 3T3-L1 cells exposed to TCM was significantly greater than by cells exposed to $\mathrm{CM}(\mathrm{P}<0.05$; Fig. $2 \mathrm{~A})$. This result suggests that factors released by inflamed BPH-1 cells infected with T. vaginalis play a role in the recruitment of 3T3-L1 cells.

To determine whether the conditioned medium from $T$. vaginalis-stimulated BPH-1 cells (TCM) is involved in the production of leptin by adipocyte, 3T3-L1 preadipocytes were allowed to develop into mature adipocytes (Fig. 1C). The mature 3T3-L1 cells were then stimulated with TCM and found to release higher levels of CXCL1, IL-6, CCL2 than cells incubated with $\mathrm{CM}$ or medium only $(P<0.05$; Fig. $2 \mathrm{~B})$; especially, production of leptin mRNA and protein was also increased by TCM (Fig. 2C, D). This means that the T. vaginalis-induced inflammatory mediators of BPH-1 cells triggered the inflammatory response of adipocytes, including leptin production. The conditioned media from mature adipocytes incubated with TCM and CM were designated ATCM and ACM, respectively.

\section{Expression of leptin receptor in prostate cells exposed to ATCM}

The effects of leptin are mediated by the transmembrane leptin receptor (OBR), which belongs to the cytokine receptor superfamily [30]. It was also reported that OBR is expressed in $\mathrm{BPH}$ tissue [31]. To measure ATCM-induced expression of leptin receptor, WPMY-1 and BPH-1 cells were incubated in 10\% ATCM, and OBR was detected by immunofluorescence microscopy and western blot assay. OBR levels were elevated in both sets of ATCM-treated cells although their levels were slightly lower than in cells exposed to recombinant leptin (Fig. 3).

\section{Proliferation of prostate cells is induced by ATCM}

It is not clear whether leptin could influence on the growth of BPH although leptin was associated with proliferation and invasion of prostate cancer [32]. To determine whether conditioned media including leptin are involved in proliferation of prostate cells, BPH-1 and WPMY-1 cells were incubated with $\mathrm{CM}$, TCM, ACM, and ATCM, and the proliferation was mea- 

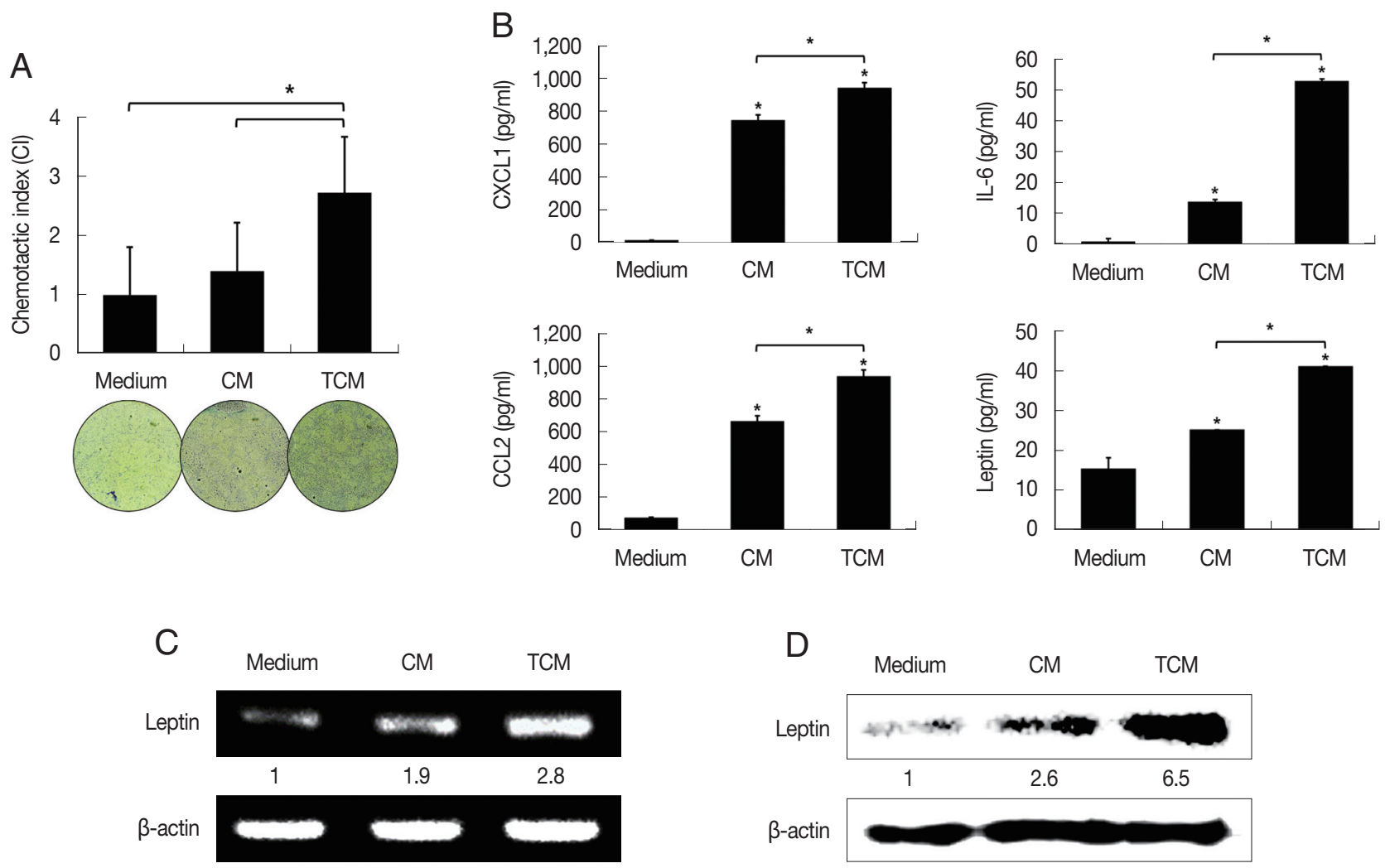

Fig. 2. Migration of preadipocytes, and adipokine expression in adipocytes exposed to TCM. The effect of TCM on the migration of preadipocyte was examined. The migration of 3T3-L1 cells was assessed by counting the number of cells that migrated through a membrane to a lower well containing TCM or CM over 24 hr. The graph shows relative preadipocyte migration (A). Production of adipokines by mature adipocytes exposed to TCM was measured by ELISA (B). mRNA and protein levels of leptin produced by mature adipocytes exposed to TCM were detected by RT-PCR (C) and western blotting (D), respectively. TCM, culture supernatant from BPH epithelial cells stimulated with T. vaginalis; CM, culture supernatant from BPH epithelial cells; Medium, DMEM medium. ${ }^{*} P<0.05$.

A WPMY-1

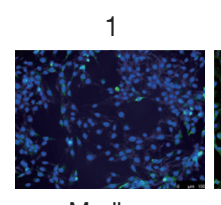

Medium

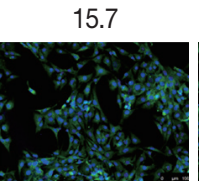

ACM
80.7

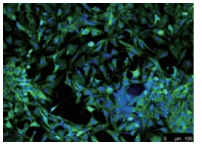

ATCM

C ${ }_{\mathrm{BPH}-1}$

63.3

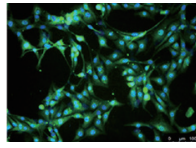

Leptin

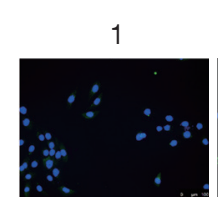

Medium

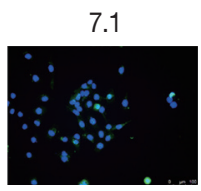

ACM

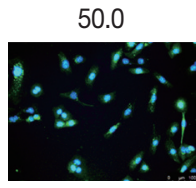

ATCM

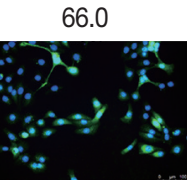

Leptin

B

WPMY-1

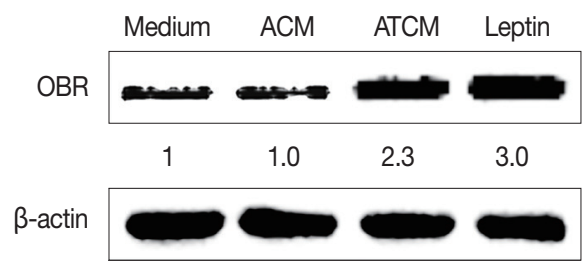

D

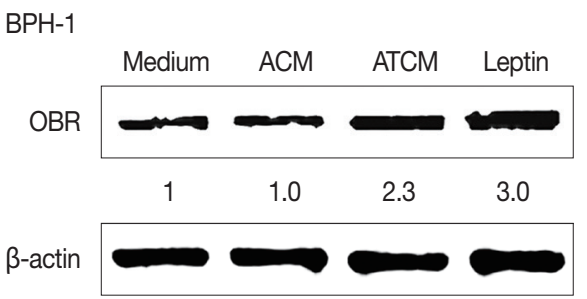

Fig. 3. Increased expression of the leptin receptor in prostate cells treated with ATCM. Leptin receptor (OBR) expression in prostate cells treated with ATCM was observed by immunofluorescence and western blot assays. Expression of OBR increased in prostate stromal cells (A, B) and BPH epithelial (C, D) cells exposed to ATCM. ATCM, culture supernatant of adipocytes exposed to TCM; ACM, culture supernatant of adipocytes exposed to CM; TCM, culture supernatant of BPH epithelial cells exposed to T. vaginalis; CM, culture supernatant of BPH epithelial cells; Leptin, recombinant leptin; Medium, culture medium of prostate cells. 

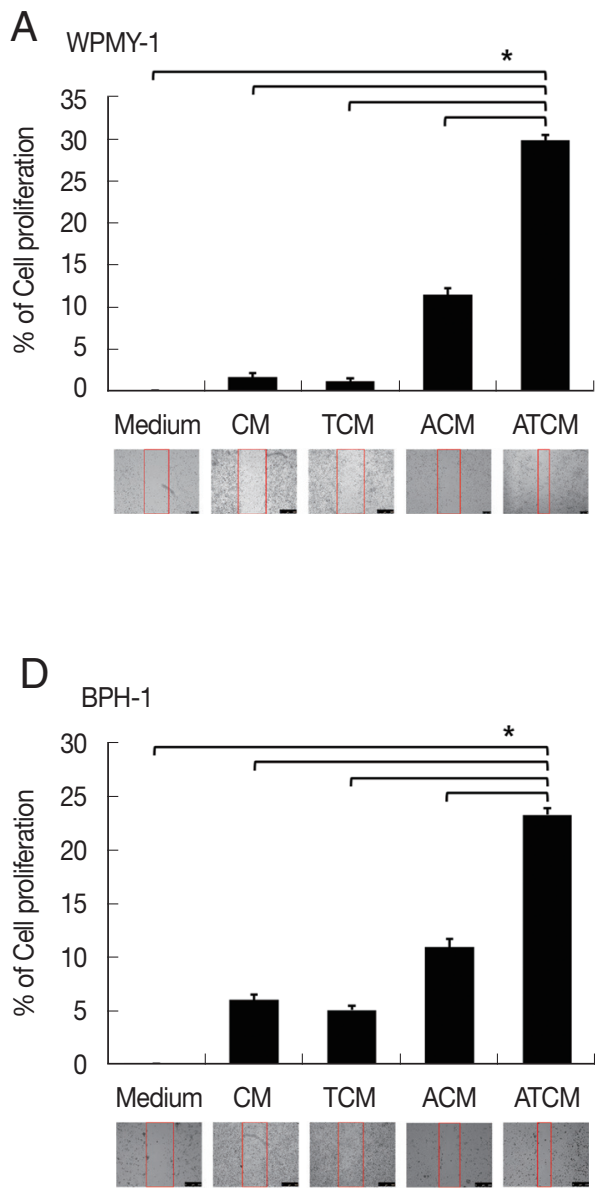

B

WPMY-1
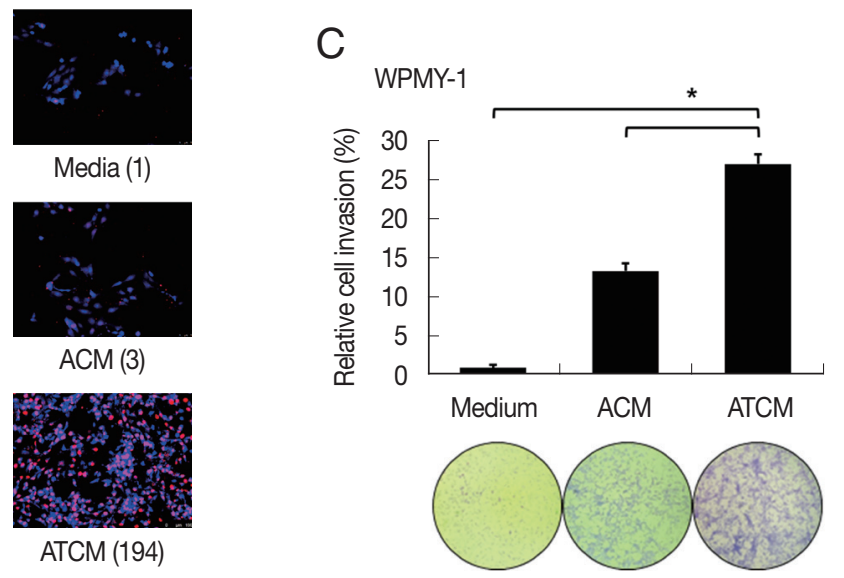

E

$\mathrm{BPH}-1$
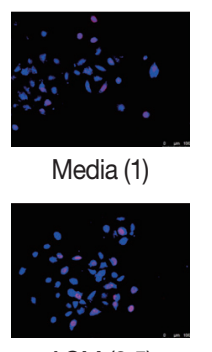

ACM (3.5)

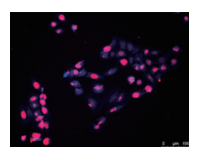

$\operatorname{ATCM}(35.5)$

Fig. 4. Increased proliferation of prostate cells incubated with ATCM. Wound healing and BrdU assays were used to measure the proliferation of prostate stromal cells (WPMY-1) and BPH epithelial cells (BPH-1) incubated with ATCM. Wound healing was observed with an inverted microscope (A, D) and DNA synthesis in proliferating cells was assessed with the bromodeoxyuridine (BrdU) assay. BrdU-positive cells were observed by fluorescence microscopy $(B, E)$. To investigate the effect of ATCM on invasiveness, the matrigel invasion assay was used. WPMY-1 cells were more invasive towards ATCM than towards medium or ACM (C). ATCM, culture supernatant of adipocytes incubated with TCM; ACM, culture supernatant of adipocytes incubated with CM; TCM, culture supernatant of BPH epithelial cells incubated with T. vaginalis; CM, culture supernatant of BPH epithelial cells; Medium, culture medium used for all prostate cells. ${ }^{*} P<0.05$ versus ATCM.

sured by BrdU and wound healing assay. The ATCM containing higher amount of leptin than other conditioned media increased wound healing $(P<0.05$; Fig. $4 \mathrm{~A}, \mathrm{D})$ and number of BrdU positive cells (Fig. 4B, E) in both prostate cells. Our data suggest that ATCM stimulates the proliferation of prostate stromal and BPH epithelial cells. Interestingly, WPMY-1 cells treated with ATCM were observed to have slightly increased proliferation compared to the results of BPH-1 cells. In addition, although no invasiveness was observed in BPH-1 cells, WPMY-1 cells showed increased invasiveness (Fig. 4C). In BPH tissue, proliferation is known to be observed 9 times in epithelial cells and 37 times in stromal cells compared to normal prostate, and the overgrowth of the stromal cells is recognized as a characteristic of BPH pathogenesis [33]. In this experiment, the increased mobility, multiplication and invasiveness of the prostate stromal cell were in line with the characteristics of BPH tissue.

\section{Expression of leptin signaling molecules in prostate cells exposed to ATCM}

Leptin binding to OBR has been reported to activate the classical JAK2/STAT3 pathway [30]. The JAK2-STAT3 pathway 
A

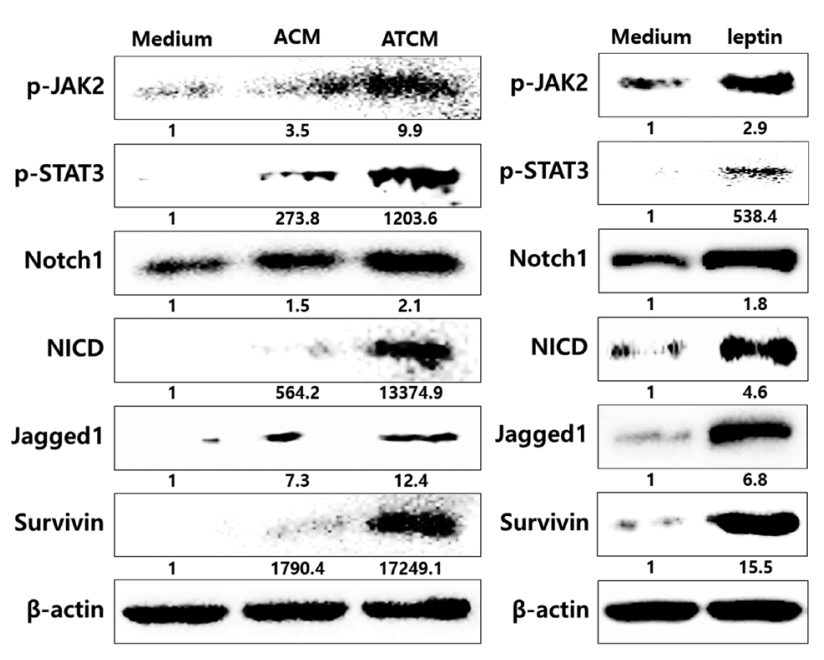

\section{B $\quad$ BPH-1}

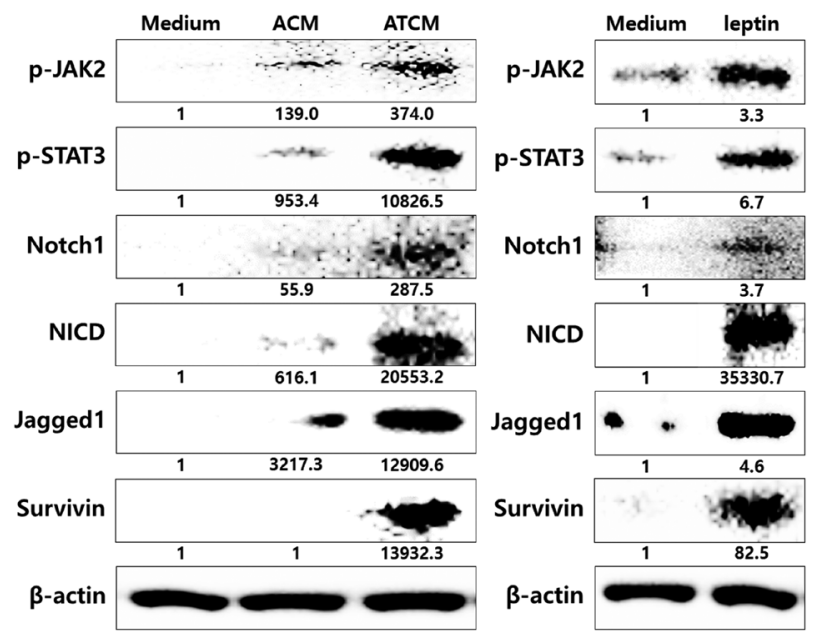

Fig. 5. Increased expression of leptin signaling molecules in prostate cells exposed to ATCM. Expression of leptin signaling molecules such as JAK2/STAT3, Notch1/Jagged1, NICD and survivin was increased by treatment with ATCM or recombinant leptin in prostate stromal (A) and BPH-1 cells (B). ATCM, culture supernatant of adipocytes exposed to TCM; ACM, culture supernatant of adipocytes exposed to $\mathrm{CM}$; TCM, culture supernatant of BPH epithelial cells exposed to T. vaginalis; CM, culture supernatant of BPH epithelial cells; Leptin, recombinant leptin; Medium, culture medium of prostate cells; NICD, Notch intracellular domain.

stimulates proliferation, angiogenesis, and anti-apoptotic events in normal and malignant cells expressing OBR. Leptin signaling also interacts with Notch, which is involved in tumor progression $[23,34]$. To probe whether the leptin signaling molecules are induced by ATCM, protein levels of leptin signaling molecules were measured in the prostate cells incubated with ATCM. Downstream leptin signaling components such as JAK2/STAT3, Notch1/Jagged1, and survivin also increased in response to ATCM in both sets of prostate cells (prostate stromal and BPH-1 cells) (Fig. 5). Similar results were obtained when recombinant leptin was used.

\section{Inhibition of OBR reduces expression of leptin signal molecules and proliferation of Prostate cells}

To investigate the role of OBR in leptin signaling of prostate cells exposed to ATCM, the cells were treated with ATCM together with anti-OBR antibody. Production of JAK2/STAT3 and Notch/Jagged was markedly inhibited by the anti-OBR antibody $(P<0.05 ;$ Fig. 6$)$. This indicates that ATCM activates the leptin signal pathway via OBR. When the OBR was blocked, ATCM-induced proliferation of prostate cells also decreased. Moreover, inhibition of leptin downstream signaling using a JAK inhibitor (ruxolitinib) or a Notch inhibitor (DAPT) reduced prostate cell proliferation $(P<0.05 ;$ Fig. 7$)$, which shows that the leptin signaling pathway contributes to proliferation.
The use of isotype-matched antibodies as a control had no effect on cell proliferation (data not shown). Our findings indicate that leptin-OBR signaling is involved in the proliferation of WPMY-1 and BPH-1 cells.

OBR expression slightly increased in BPH tissue in obese $\mathrm{BPH}$ patients compared to lean patients

A total of 94 patients with benign prostatic hyperplasia who underwent surgical resection in Hanyang University Hospital (Seoul, Korea) from 2016 to 2018 were identified. Among them, ten obese and 10 lean patients were categorized by BMI level. The patients whose mean of BMI level was 28 classified into the obese group. The lean group has had an average BMI level of 23. OBR expression was detected immunohistochemically with rabbit polyclonal anti-OBR antibody. Intensity of OBR expression was represented as a numerical score from 0 to 5 based on proportion of clusters of immunopositive cells. The OBR was slightly more expressed in human BPH tissue from obese patients than lean patients (Fig. 8).

\section{DISCUSSION}

Trichomonas vaginalis is mostly known as a surface-dwelling parasite, but it has been detected in endo-epithelial cells and in sub-epithelial tissues because of its ability to invade $[5,6]$. 

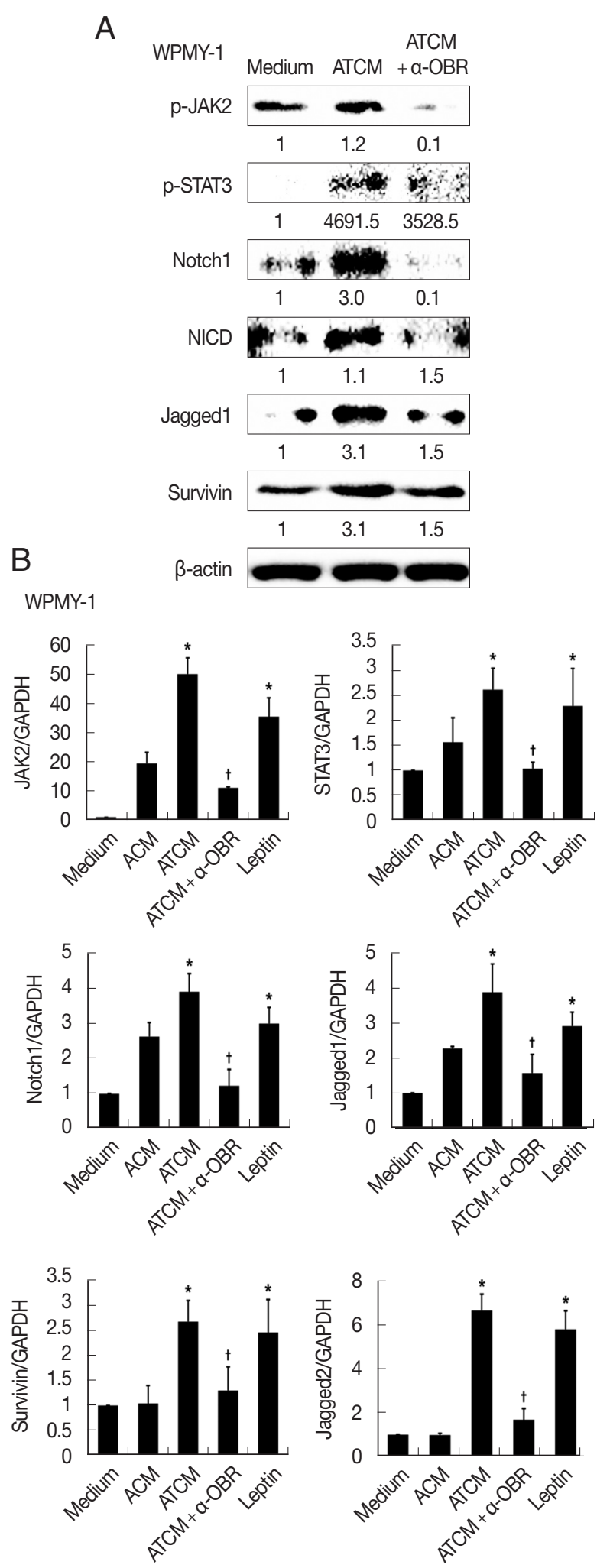

C

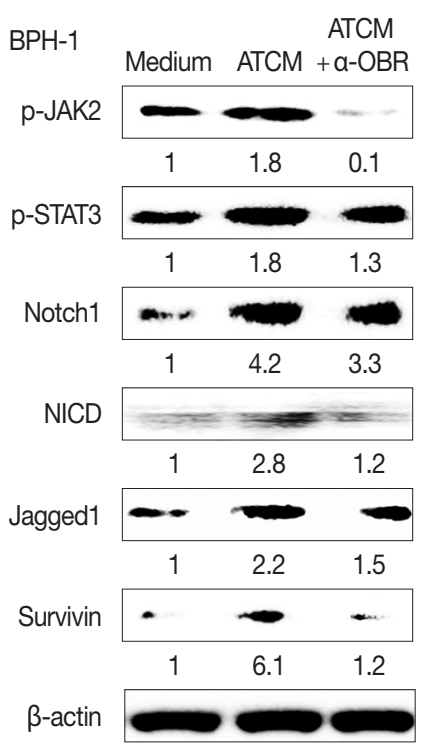

$\mathrm{BPH}-1$
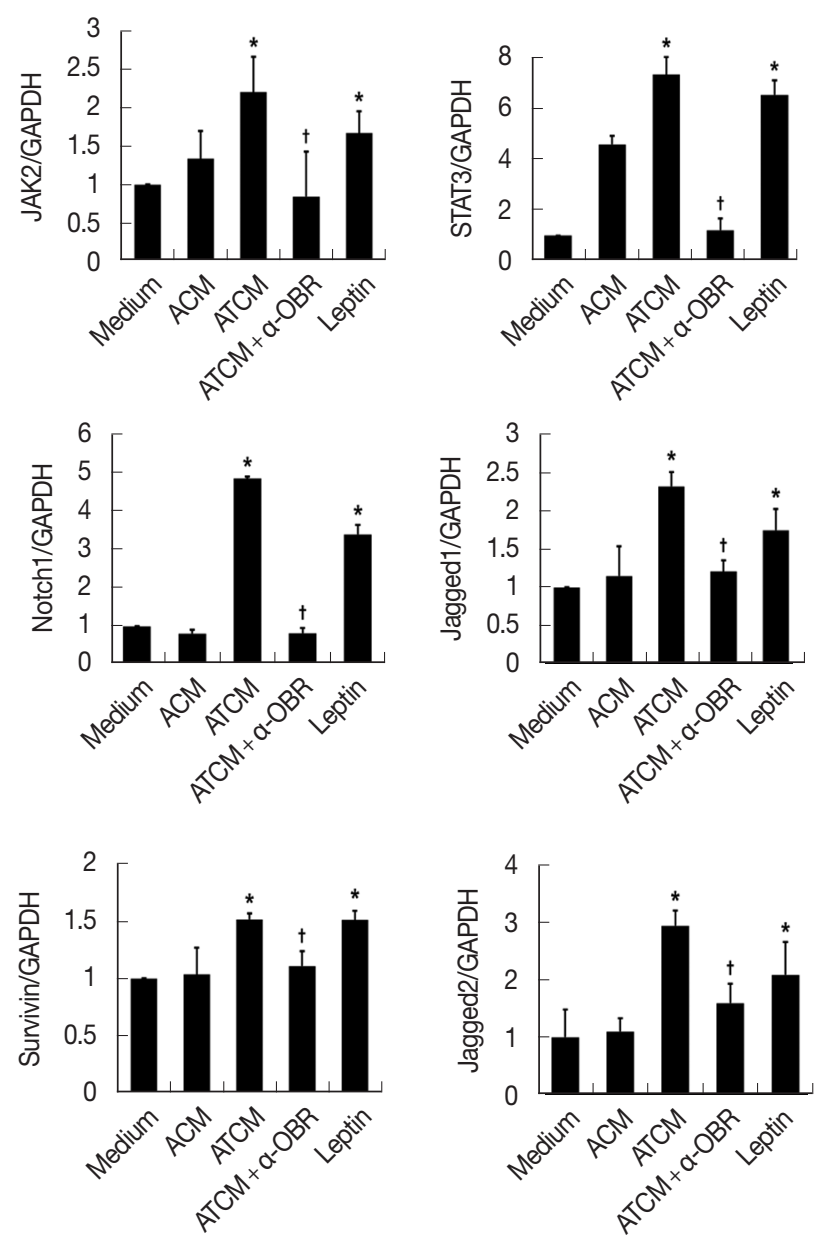

Fig. 6. Blockade of the leptin receptor reduces the expression of downstream signaling molecules in prostate cells stimulated with ATCM. To investigate the expression of downstream leptin signaling molecules in prostate cells exposed to ATCM, prostate stromal cells (WPMY-1) and BPH epithelial cells (BPH-1) were incubated with ATCM or ATCM+anti-OBR antibody (a-OBR). Protein and mRNA levels were measured by western blot $(A, C)$ and $Q-P C R(B, D)$, respectively. ATCM, culture supernatant of adipocytes incubated with TCM; ACM, culture supernatant of adipocytes incubated with CM; TCM, culture supernatant of BPH epithelial cells incubated with T. vaginalis; Medium, culture medium of prostate cells; NICD, Notch intracellular domain. ${ }^{*} P<0.05$ versus medium. ${ }^{+} P<0.05$ versus ATCM. 
A

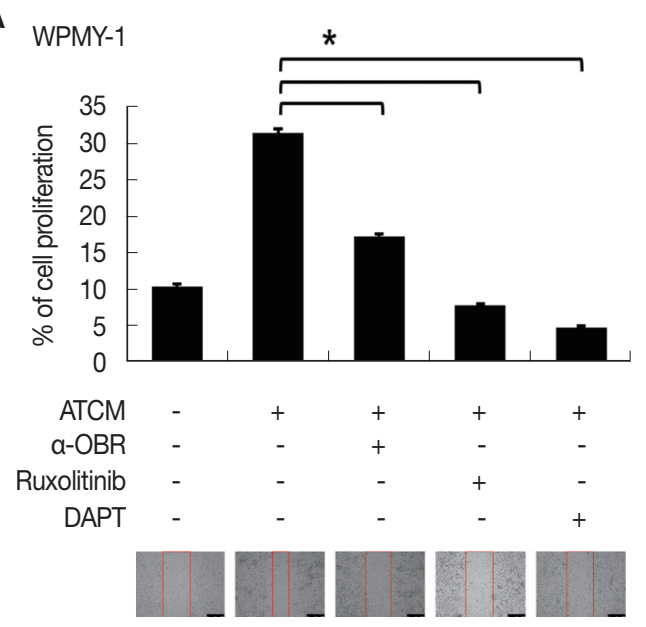

B

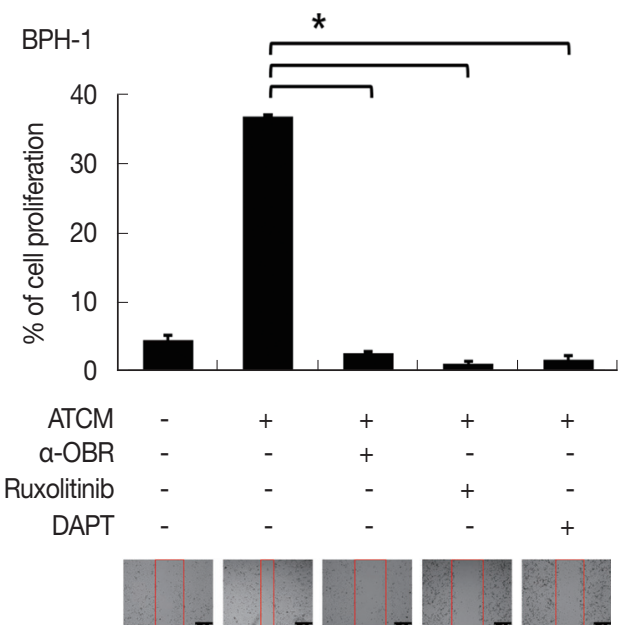

Fig. 7. Inhibition of leptin signaling decreases the proliferation of prostate cells. To confirm the involvement of leptin signaling in the growth of prostate stromal (WPMY-1) and BPH epithelial (BPH-1) cells, the leptin receptor (OBR), JAK or Notch were inhibited, and the wound healing assay was conducted. Anti-OBR antibody (a-OBR) and the JAK inhibitor (ruxolitinib) and Notch inhibitor (DAPT) decreased the proliferation of both prostate cell types in response to ATCM. ATCM, culture supernatant of adipocytes incubated with TCM; TCM, culture supernatant of BPH epithelial cells incubated with T. vaginalis. ${ }^{*} P<0.05$ versus ATCM.
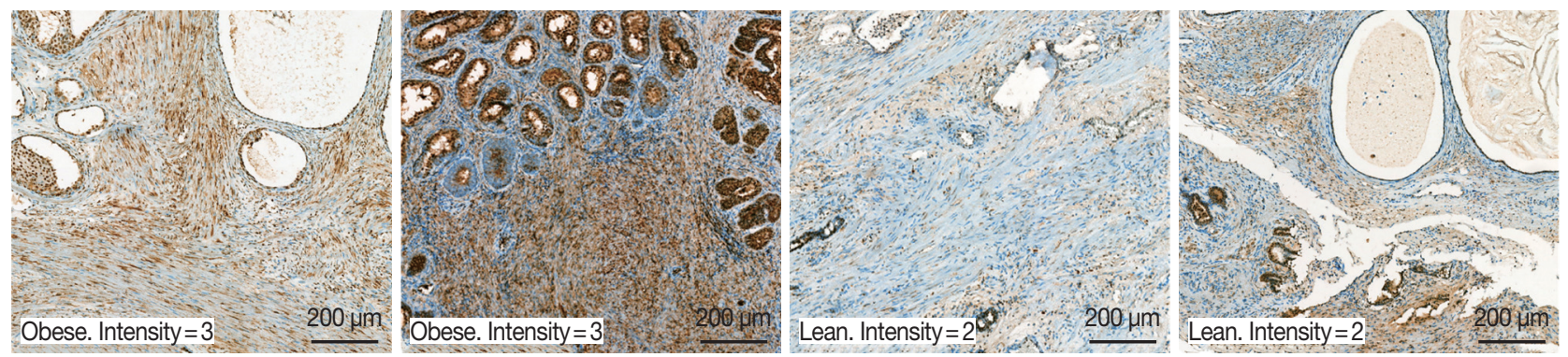

Fig. 8. Leptin receptor (OBR) expression slightly increased in BPH tissue in obese BPH patients compared to lean patients. OBR expression was detected immunohistochemically with rabbit polyclonal anti-OBR antibody. Intensity of OBR expression was represented as a numerical score from 0 to 5 based on proportion of clusters of immunopositive cells. The OBR was slightly more expressed in human $\mathrm{BPH}$ tissue from obese patients than lean patients. Bar $=200 \mu \mathrm{m}$.

Because T. vaginalis infection has been found in over $70 \%$ of the male sexual partners of infected women, the number of infected men must be not ignored [35]. 19.9\% of male nongonococcal urethritis (NGU) patients were reported to be infected with $T$. vaginalis, and BPH may be associated with chronic retention of T. vaginalis in the prostate gland $[5,36]$. Microenvironmental factors such as infection and wounding may alter cellular equilibria leading to BPH or prostate cancer [37]. A little is known about the proliferative mechanism of prostate cells. Siejka et al. [38] reported that bidirectional stromal-epithelial interactions occur in the prostate gland; when supernatants of prostate stromal cells (or BPH epithelial cells) were added to BPH epithelial cells (or prostate stromal cells), proliferation increased. In this context, our previous studies showed that the proliferation of inflamed BPH epithelial cells infected with T. vaginalis induced the multiplication of prostate stromal cells via crosstalk with mast cells, and IL-6 released by the proliferating prostate stromal cells stimulated the proliferation of BPH epithelial cells [26,27].

As people's lifestyles have changed, obesity has become an important issue even in Asia. Obesity is related to social problems as well as personal health care. It causes many diseases, and is closely linked to diabetes, hypertension, malignancy, etc. [39]. Adipose tissue affects the endocrine and immune systems by secreting cytokines and hormones. These cytokine-like mediators produced by adipose tissue are called adipokines, and include leptin, adiponectin and resistin [40]. Leptin was first identified as a key molecule in the regulation of food in- 
take and body weight. It also has a role in wound healing, reproduction, hematogenesis, and regulation of insulin and testosterone [41,42].

Clinical BPH, a condition involving abnormal progressive growth of prostate tissue is a common disease in elderly men, and causes lower urinary tract syndrome [43]. As the average human lifespan increases, it is becoming recognized as an important disease that affects quality of life and in which $\mathrm{BPH}$, hormonal alterations, metabolic syndrome and obesity play key roles [13-15]. Obesity, central or general, is thought to be a risk factor for $\mathrm{BPH}$ [17]. The molecular mechanisms associated with the progression and aggravation of BPH in obesity are not known. In this study, we investigated whether BPH proliferation was induced by adipocyte leptin, which was stimulated by $T$. vaginalis infection in prostate cells.

The role of leptin has been much studied in breast cancer; Leptin may act via JAK/STAT signaling to increase breast cancer tissue proliferation [44]. It has been implicated in the higher incidence of aggressiveness, and appears to be involved in the proliferation and migration of breast cancer cells [45]. Guo et al. [46] have been reported that leptin induces Notch, and the Notch target gene, IL-1, and VEGF, and their levels of these molecules in breast cancers are correlated with the occurrence of metastases and lower survival. However, the function of leptin in the prostate has not been much studied. There are a few reports that leptin is associated with proliferation of the prostate; Leptin seems to have an important role in maintaining the physiological growth of the prostate. In hyperplasic prostate tissue, leptin treatment increased cellular proliferation and decreased apoptosis [47]. It is also reported to stimulate the proliferation of a BPH-1 cell and a prostate cancer cell line (PC-3 cell) via estrogen metabolism [48]. Leptin expression in prostate cancer tissue is significantly higher than in $\mathrm{BPH}$, although expression of the leptin receptor (OBR) was similar in $\mathrm{BPH}$ and prostate cancer tissue [31]. Therefore, it was recently suggested that leptin might be a novel target for therapeutic intervention in prostatic disorders [48]. In agreement with the above reports, proliferation of prostate cells in our study was upregulated upon exposure to adipocyte-conditioned medium (ATCM) which contained leptin, and inhibition of the OBR reduced leptin-induced proliferation. Thus, this study provides the first experimental evidence that the leptin-OBR signal pathway plays a role in prostate cell proliferation.

There are 6 isoforms of OBR, which exerts various physiological effects in response to binding by leptin, which is a 16
kDa non-glycosylated protein encoded by the Ob gene [49]. OBR belongs to a superfamily of class I cytokine receptors, which typically contain a cytokine receptor-homologous domain in their extracellular regions [19]. As with other class I cytokine receptors, the leptin signal is reported to be transmitted mainly by the JAK/STAT pathway. Binding of leptin to OBR leads to tyrosine phosphorylation of JAK1 and JAK2, and phosphorylation of downstream STAT transcription factors [50]. In the case of lung cancer cell, leptin was shown to promote growth, invasiveness, and migration with concomitant activation of JAK/STAT, PI3K/AKT and ERK signaling [22]. In this study, adipocyte leptin was found to stimulate the OBR and the JAK2/STAT3 signal pathway in prostate cells; inhibition of the OBR and JAK decreased leptin-induced proliferation of prostate cells. Besides, the OBR was slightly more expressed in BPH tissue in obese than in lean patients (Fig. 8).

Notch is a downstream signal of leptin, and is highly conserved in evolution. The Notch signal is very important in determining cell-fate decisions from proliferation, differentiation and apoptosis to cancer cell invasion and metastasis [51]. The Notch family consists of 4 receptors (Notch 1-4) and has 5 ligands named Jagged 1, 2, Delta-like 1, 3, and 4 [22]. In response to ligand binding, the Notch receptor undergoes proteolytic cleavage, resulting in the release of the Notch intracellular domain (NICD). NICD then enters the nucleus and forms a complex with RBP-jk (also known as CSL) and histone acetyltransferase $(\mathrm{CBP} / \mathrm{p} 300)$ leading to the expression of Notch target genes such as survivin [52]. The notch signal has been reported to play critical roles in intraepithelial neoplasia formation in prostate cancer, and in proliferation and angiogenesis in breast and pancreatic cancers [53,54]. But the Notch signal hitherto had no known role in BPH enlargement. In this study, the leptin-OBR signal activated Notch signaling, and inhibition of Notch reduced the proliferation of prostate stromal cells and BPH epithelial cells. This result suggests for the first time that Notch signaling may be involved in the proliferation of BPH cells via the leptin-OBR signal pathway. Meanwhile, Mullen et al. [23] proposed a signal cascade that leptin induces Notch in breast cancer through JAK2/STAT3. Although our study revealed that JAK2/STAT3 is involved in the leptin-OBR signaling pathway, the signaling cascade has not been well documented. Further research is needed.

Survivin, a member of the inhibitor-of-apoptosis protein family, mainly acts to suppress apoptosis and regulate cell division [55]. Although not expressed in normal adult differenti- 


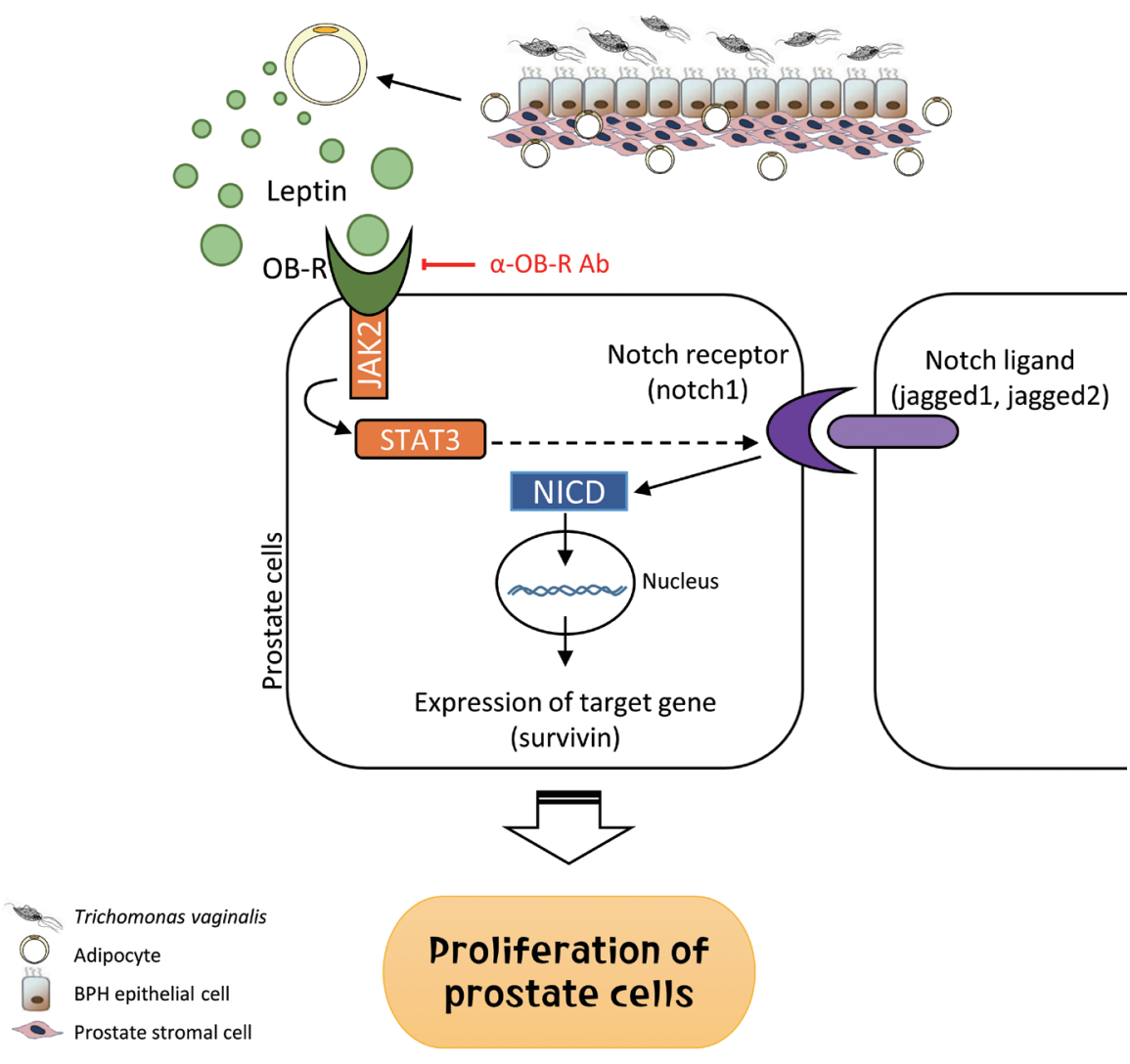

Fig. 9. Role of adipocyte leptin in the proliferation of prostate cells infected with Trichomonas vaginalis. We investigated whether inflammation from Trichomonas vaginalis infection is involved in the proliferation of benign prostatic hyperplasia (BPH) in the obese state. Inflammatory mediators released by BPH epithelial cells infected with T. vaginalis triggered adipocyte migration and activation. Leptin produced from the activated adipocytes induced prostate cell proliferation through the leptin-OBR signaling pathway.

ated tissue, it is present in most cancers, regardless of lineage, differentiation and histological type [56]. Survivin expression correlates with unfavorable disease outcomes through increased aggressiveness and metastasis in colorectal, pancreatic, breast and ovarian cancers $[55,57,58]$. Downstream effector molecules of leptin signaling (such as Stat3 and Akt) are reported to participate in the regulation of survivin expression [59]. In our case, expression of survivin increased in response to ATCM. Inhibition of the leptin-OBR pathway reduced survivin levels and consequently decreased leptin-induced proliferation of the prostate cells. This result is probably the first evidence that survivin is involved in the leptin-induced proliferation of prostate cells.

In summary, inflammatory mediators released by BPH epithelial cells in response to infection with T. vaginalis induce migration and activation of adipocytes. The activated adipocytes then stimulate the proliferation of prostate cells through leptin-OBR signaling. Therefore, it is likely that $T$. vaginalis contributes to prostate enlargement via adipocyte leptin re- leased as a result of inflammation of the prostate (Fig. 9).

\section{ACKNOWLEDGMENT}

This research was supported by the Basic Science Program through the National Research Foundation of Korea (NRF) funded by the Ministry of Science and ICT (NRF-2017R1A2B4002072).

\section{CONFLICT OF INTERST}

The authors declare that they have no conflicts of interest.

\section{REFERENCES}

1. Abdolrasouli A, Amin A, Baharsefat M, Roushan A, Hemmati Y. Moraxella catarrhalis associated with acute urethritis imitating gonorrhoea acquired by oral-genital contact. Int J STD AIDS 2007; 18: 579-580. http://doi.org/10.1258/095646207781439775

2. Newman L, Rowley J, Vander Hoorn S, Wijesooriya NS, Unemo M, Low N, Stevens G, Gottlieb S, Kiarie J, Temmerman M. Glob- 
al estimates of the prevalence and incidence of four curable sexually transmitted infections in 2012 based on systematic review and global reporting. PLoS One 2015; 10: e0143304. http://doi. org/10.1371/journal.pone.0143304

3. Sutcliffe S, Neace C, Magnuson NS, Reeves R, Alderete JF. Trichomonosis, a common curable STI, and prostate carcinogenesis--a proposed molecular mechanism. PLoS Pathog 2012; 8: e1002801. http://doi.org/10.1371/journal.ppat.1002801

4. Lee JJ, Moon HS, Lee TY, Hwang HS, Ahn MH, Ryu JS. PCR for diagnosis of male Trichomonas vaginalis infection with chronic prostatitis and urethritis. Korean J Parasitol 2012; 50: 157-159. http://doi.org/10.3347/kjp.2012.50.2.157

5. Mitteregger D, Aberle SW, Makristathis A, Walochnik J, Brozek W, Marberger M, Kramer G. High detection rate of Trichomonas vaginalis in benign hyperplastic prostatic tissue. Med Microbiol Immunol 2012; 201: 113-116. http://doi.org/10.1007/s00430-0110205-2

6. Gardner WA Jr., Culberson DE, Bennett BD. Trichomonas vaginalis in the prostate gland. Arch Pathol Lab Med 1986; 110: 430-432.

7. Jang KS, Han IH, Lee SJ, Yoo J, Kim YS, Sim S, Ryu JS. Experimental rat prostatitis caused by Trichomonas vaginalis infection. Prostate 2019; 79: 379-389. http://doi.org/10.1002/pros.23744

8. St Sauver JL, Jacobsen SJ. Inflammatory mechanisms associated with prostatic inflammation and lower urinary tract symptoms. Curr Prostate Rep 2008; 6: 67-73. http://doi.org/10.1007/s11918008-0011-5

9. Ørsted DD, Bojesen SE. The link between benign prostatic hyperplasia and prostate cancer. Nat Rev Urol 2013; 10: 49-54. http://doi.org/10.1038/nrurol.2012.192

10. Begley LA, Kasina S, MacDonald J, Macoska JA. The inflammatory microenvironment of the aging prostate facilitates cellular proliferation and hypertrophy. Cytokine 2008; 43: 194-199. http://doi.org/10.1016/j.cyto.2008.05.012

11. Penna G, Fibbi B, Amuchastegui S, Cossetti C, Aquilano F, Laverny $\mathrm{G}$, Gacci M, Crescioli C, Maggi M, Adorini L. Human benign prostatic hyperplasia stromal cells as inducers and targets of chronic immuno-mediated inflammation. J Immunol 2009; 182: 4056-4064. http://doi.org/10.4049/jimmunol.0801875

12. Berry SJ, Coffey DS, Walsh PC, Ewing LL. The development of human benign prostatic hyperplasia with age. J Urol 1984; 132: 474-479. https://doi.org/10.1016/S0022-5347(17)49698-4

13. La Vignera S, Condorelli RA, Russo GI, Morgia G, Calogero AE. Endocrine control of benign prostatic hyperplasia. Andrology 2016; 4: 404-411. http://doi.org/10.1111/andr.12186

14. De Nunzio C, Aronson W, Freedland SJ, Giovannucci E, Parsons JK. The correlation between metabolic syndrome and prostatic diseases. Eur Urol 2012; 61: 560-570. http://doi.org/10.1016/j.eururo. 2011.11.013

15. Parsons JK, Sarma AV, McVary K, Wei JT. Obesity and benign prostatic hyperplasia: clinical connections, emerging etiological paradigms and future directions. J Urol 2013; 189 (suppl): 102106. http://doi.org/10.1016/j.juro.2012.11.029

16. Corona G, Vignozzi L, Rastrelli G, Lotti F, Cipriani S, Maggi M. Be- nign prostatic hyperplasia: a new metabolic disease of the aging male and its correlation with sexual dysfunctions. Int J Endocrinol 2014; 2014: 329456. http://doi.org/10.1155/2014/329456

17. Parikesit D, Mochtar CA, Umbas R, Hamid ARAH. The impact of obesity towards prostate diseases. Prostate Int 2016; 4: 1-6. http://doi.org/10.1016/j.prnil.2015.08.001

18. Teixeira L, Moreira J, Melo J, Bezerra F, Marques RM, Ferreirinha P, Correia A, Monteiro MP, Ferreira PG, Vilanova M. Immune response in the adipose tissue of lean mice infected with the protozoan parasite Neospora caninum. Immunology 2015; 145: 242257. http://doi.org/10.1111/imm.12440

19. Margetic S, Gazzola C, Pegg GG, Hill RA. Leptin: a review of its peripheral actions and interactions. Int J Obes Relat Metab Disord 2002; 2: 1407-1433. http://doi.org/10.1038/sj.ijo.0802142

20. Szyszka M, Tyczewska M, Milecka P, Jopek K, Celichowski P, Malendowicz LK, Rucinski M. Effects of leptin on leptin receptor isoform expression and proliferative activity in human normal prostate and prostate cancer cell lines. Oncol Rep 2018; 39: 182192. http://doi.org/10.3892/or.2017.6066

21. Li J, Han X. Adipocytokines and breast cancer. Curr Probl Cancer 2018; 42: 208-214. http://doi.org/10.1016/j.currproblcancer.2018.01.004

22. Zheng XJ, Yang ZX, Dong YJ, Zhang GY, Sun MF, An XK, Pan LH, Zhang SL. Downregulation of leptin inhibits growth and induces apoptosis of lung cancer cells via the Notch and JAK/STAT3 signaling pathways. Biology Open 2016; 5: 794-800. http://doi.org/10.1242/ bio. 017798

23. Mullen M, Gonzalez-Perez RR. Leptin-induced JAK/STAT signaling and cancer growth. Vaccines (Basel) 2016; 4: 26. http://doi. org/10.3390/vaccines4030026

24. Harbuzariu A, Gonzalez-Perez RR. Leptin-Notch axis impairs 5-fluorouracil effects on pancreatic cancer. Oncotarget 2018; 9: 18239-18253. http://doi.org/10.18632/oncotarget.24435

25. Jung JH, Ahn SV, Song JM, Chang SJ, Kim KJ, Kwon SW, Park SY, Koh SB. Obesity as a risk factor for prostatic enlargement: a retrospective cohort study in Korea. Int Neurourol J 2016; 20: 321328. http://doi.org/10.5213/inj.1632584.292

26. Kim JH, Kim SS, Han IH, Sim S, Ahn MH, Ryu JS. Proliferation of prostate stromal cell induced by benign prostatic hyperplasia epithelial cell stimulated with Trichomonas vaginalis via crosstalk with mast cell. Prostate 2016; 76: 1431-1444. http://doi.org/10.1002/ pros. 23227

27. Kim JH, Han IH, Kim YS, Noh CS, Ryu JS. Proliferation of prostate epithelia induced by IL-6 from stroma reacted with Trichomonas vaginalis. Parasite Immunol 2018; 40: e12531. http://doi. org/10.1111/pim.12531

28. Chung HY, Kim JH, Han IH, Ryu JS. Polarization of M2 Macrophages by Interaction between Prostate Cancer Cells Treated with Trichomonas vaginalis and Adipocytes. Korean J Parasitol 2020; 58: 217-227. https://doi.org/10.3347/kjp.2020.58.3.217

29. Xie H, Li L, Zhu G, Dang Q, Ma Z, He D, Chang L, Song W, Chang HC, Krolewski JJ, Nastiuk KL, Yeh S, Chang C. Infiltrated pre-adipocytes increase prostate cancer metastasis via modulation of the miR-301a/androgen receptor (AR)/TGF-beta1/Smad/ 
MMP9 signals. Oncotarget 2015; 6: 12326-12339. http://doi. org/10.18632/oncotarget.3619

30. Yamashita T, Murakami T, Otani S, Kuwajima M, Shima K. Leptin receptor signal transduction: OBRa and OBRb of fa type. Biochem Biophys Res Commun 1998; 246: 752-759. http://doi. org/10.1006/bbrc.1998.8689

31. Hoon Kim J, Lee SY, Myung SC, Kim YS, Kim TH, Kim MK. Clinical significance of the leptin and leptin receptor expressions in prostate tissues. Asian J Androl 2008; 10: 923-928. http://doi. org/10.1111/j.1745-7262.2008.00438.x

32. Noda T, Kikugawa T, Tanji N, Miura N, Asai S, Higashiyama S, Yokoyama M. Longterm exposure to leptin enhances the growth of prostate cancer cells. Int J Oncol 2015; 46: 1535-1542. http:// doi.org/10.3892/ijo.2015.2845

33. Claus $S$, Wrenger $M$, Senge T, Schulze H. Immunohistochemical determination of age related proliferation rates in normal and benign hyperplastic human prostates. Urol Res 1993; 21: 305308. http://doi.org/10.1007/BF00296825

34. Harbuzariu A, Rampoldi A, Daley-Brown DS, Candelaria P, Harmon TL, Lipsey CC, Beech DJ, Quarshie A, Ilies GO, GonzalezPerez RR. Leptin-Notch signaling axis is involved in pancreatic cancer progression. Oncotarget 2017; 8: 7740-7752. http://doi. org/10.18632/oncotarget.13946

35. Hobbs MM, Kazembe P, Reed AW, Miller WC, Nkata E, Zimba D, Daly CC, Chakraborty H, Cohen MS, Hoffman I. Trichomonas vaginalis as a cause of urethritis in Malawian men. Sex Transm Dis 1999; 26: 381-387. http://doi.org/10.1097/00007435-19990800000003

36. Schwebke JR, Hook EW 3rd. High rates of Trichomonas vaginalis among men attending a sexually transmitted diseases clinic: implications for screening and urethritis management. J Infect Dis 2003; 188: 465-468. http://doi.org/10.1086/376558

37. Cunha GR, Hayward SW, Wang YZ, Ricke WA. Role of the stromal microenvironment in carcinogenesis of the prostate. Int J Cancer 2003; 107: 1-10. http://doi.org/10.1002/ijc.11335

38. Siejka A, Schally AV, Barabutis N. The effect of LHRH antagonist cetrorelix in crossover conditioned media from epithelial (BPH1) and stromal (WPMY-1) prostate cells. Horm Metab Res 2014; 46: 21-26. http://doi.org/10.1055/s-0033-1349127

39. van Kruijsdijk RCM, van der Wall E, Visseren FLJ. Obesity and cancer: the role of dysfunctional adipose tissue. Cancer Epidemiol Biomarkers Prev 2009; 18: 2569-2578. http://doi.org/10.1158/10559965.EPI-09-0372

40. Abella V, Scotece M, Conde J, Pino J, Gonzalez-Gay MA, GómezReino JJ, Mera A, Lago F, Gómez R, Gualillo O. Leptin in the interplay of inflammation, metabolism and immune system disorders. Nat Rev Rheumatol 2017; 13: 100-109. http://doi.org/10.1038/ nrrheum.2016.209

41. Sierra-Honigmann MR, Nath AK, Murakami C, García-Cardeña G, Papapetropoulos A, Sessa WC, Madge LA, Schechner JS, Schwabb MB, Polverini PJ, Flores-Riveros JR. Biological action of leptin as an angiogenic factor. Science 1998; 281: 1683-1686. http://doi.org/10.1126/science.281.5383.1683
42. Somasundar P, Yu AK, Vona-Davis L, McFadden DW. Differential effects of leptin on cancer in vitro. J Surg Res 2003; 113: 5055. http://doi.org/10.1016/s0022-4804(03)00166-5

43. Bianchi-Frias D, Vakar-Lopez F, Coleman IM, Plymate SR, Reed MJ, Nelson PS. The effects of aging on the molecular and cellular composition of the prostate microenvironment. PLoS One 2010; 5. http://doi.org/10.1371/journal.pone.0012501

44. Park JW, Zhao L, Willingham MC, Cheng SY. Inhibition of STAT3 signaling blocks obesity-induced mammary hyperplasia in a mouse model. Am J Cancer Res 2017; 7: 727-739. https:// www.ncbi.nlm.nih.gov/pmc/articles/PMC5385655/

45. Battle M, Gillespie C, Quarshie A, Lanier V, Harmon T, Wilson K, Torroella-Kouri M, Gonzalez-Perez RR. Obesity induced a leptinNotch signaling axis in breast cancer. Int J Cancer 2014; 134: 1605-1616. http://doi.org/10.1002/ijc.28496

46. Guo S, Gonzalez-Perez RR. Notch, IL-1 and leptin crosstalk outcome (NILCO) is critical for leptin-induced proliferation, migration and VEGF/VEGFR-2 expression in breast cancer. PLoS One 2011; 6: e21467. http://doi.org/10.1371/journal.pone.0021467

47. Leze E, Alves-Pereira JL, Colli S, Cavalcante FS, José Sampaio F, da Fonte Ramos C. Leptin regulates proliferation and apoptosis in human prostate. ScientificWorldJournal 2012; 2012: 842301. http://doi.org/10.1100/2012/842301

48. Habib CN, Al-Abd AM, Tolba MF, Khalifa AE, Khedr A, Mosli HA, Abdel-Naim AB. Leptin influences estrogen metabolism and accelerates prostate cell proliferation. Life Sci 2015; 121: 1015. http://doi.org/10.1016/j.lfs.2014.11.007

49. Friedman JM, Halaas JL. Leptin and the regulation of body weight in mammals. Nature 1998; 395: 763-770. http://doi.org/ $10.1038 / 27376$

50. Ahima R, Osei SY. Leptin and appetite control in lipodystrophy. J Clin Endocrinol Metab 2004; 89: 4254-4257. http://doi.org/ http://doi.org/10.1210/jc.2004-1232

51. Cheng P, Kumar V, Liu H, Youn JI, Fishman M, Sherman S, Gabrilovich D. Effects of notch signaling on regulation of myeloid cell differentiation in cancer. Cancer Res 2014; 74: 141-152. http:// doi.org/10.1158/0008-5472.CAN-13-1686

52. Jarriault S, Brou C, Logeat F, Schroeter EH, Kopan R, Israel A. Signalling downstream of activated mammalian Notch. Nature 1995; 377: 355-358. http://doi.org/10.1038/377355a0

53. Lipsey CC, Harbuzariu A, Daley-Brown D, Gonzalez-Perez RR. Oncogenic role of leptin and notch interleukin-1 leptin crosstalk outcome in cancer. World J Methodol 2016; 6: 43-55. http://doi. org/10.5662/wjm.v6.i1.43

54. Soylu H, Acar N, Ozbey O, Unal B, Koksal IT, Bassorgun I, Ciftcioglu A, Ustunel I. Characterization of notch signalling pathway members in normal prostate, prostatic intraepithelial neoplasia (PIN) and prostatic adenocarcinoma. Pathol Oncol Res 2016; 22: 87-94. https://doi.org/10.1007/s12253-015-9983-y

55. Altieri DC. Molecular circuits of apoptosis regulation and cell division control: the survivin paradigm. J Cell Biochem 2004; 92: 656-663. http://doi.org/10.1002/jcb.20140

56. Ambrosini G, Plescia J, Chu KC, High KA, Altieri DC. Activation- 
dependent exposure of the inter-EGF sequence Leu83-Leu88 in factor Xa mediates ligand binding to effector cell protease receptor-1. J Biol Chem 1997; 272: 8340-8345. http://doi.org/10.1074/ jbc. 272.13 .8340

57. Kawasaki H, Altieri DC, Lu CD, Toyoda M, Tenjo T, Tanigawa N. Inhibition of apoptosis by survivin predicts shorter survival rates in colorectal cancer. Cancer Res 1998; 58: 5071-5074.

58. Satoh K, Kaneko K, Hirota M, Masamune A, Satoh A, Shimosegawa T. Expression of survivin is correlated with cancer cell apoptosis and is involved in the development of human pancreatic duct cell tumors. Cancer 2001; 92: 271-278. https://doi.org/10.1002/10970142(20010715)92:2<271::AID-CNCR1319>3.0.CO;2-0

59. Knight BB, Oprea-Ilies GM, Nagalingam A, Yang L, Cohen C, Saxena NK, Sharma D. Survivin upregulation, dependent on leptin-EGFR-Notch1 axis, is essential for leptin-induced migration of breast carcinoma cells. Endocr Relat Cancer 2011; 18: 413-428. http://doi.org/10.1530/ERC-11-0075 
